\title{
Arginine vasopressin, via activation of post-junctional V1 receptors, induces contractile effects in mouse distal colon
}

\author{
Mariangela Mastropaolo, Maria Grazia Zizzo, Michelangelo Auteri, Flavia Mulè, Rosa Serio * \\ Dipartimento di Scienze e Tecnologie Biologiche, Chimiche e Farmaceutiche (STEBICEF) Laboratorio di Fisiologia generale, Università di Palermo, Viale delle Scienze, I-90128 Palermo, Italy
}

\section{A R T I C L E I N F O}

\section{Article history:}

Received 17 July 2013

Received in revised form 21 October 2013

Accepted 28 October 2013

Available online 31 October 2013

\section{Keywords:}

Arginine vasopressin

Intestinal contractility

V1 receptors

Phospholipase C

Mouse colon

\begin{abstract}
A B S T R A C T
The aim of this study was to analyze whether arginine vasopressin (AVP) may be considered a modulator of intestinal motility. In this view, we evaluated, in vitro, the effects induced by exogenous administration of AVP on the contractility of mouse distal colon, the subtype(s) of receptor(s) activated and the action mechanism. Isometric recordings were performed on longitudinal and circular muscle strips of mouse distal colon. AVP (0.001 nM-100 nM) caused concentration-dependent contractile effects only on the longitudinal muscle, antagonized by the V1 receptor antagonist, V-1880. AVP-induced effect was not modified by tetrodotoxin, atropine and indomethacin. Contractile response to AVP was reduced in $\mathrm{Ca}^{2+}$-free solution or in the presence of nifedipine, and it was abolished by depletion of calcium intracellular stores after repetitive addition of carbachol in calcium-free medium with addition of cyclopiazonic acid. U-73122, an inhibitor of the phospholipase C, effectively antagonized AVP effects, whilst it was not affected by an adenylyl cyclase inhibitor. Oxytocin induced an excitatory effect in the longitudinal muscle of distal colon at very high concentrations, effect antagonized by V-1880. The results of this study shown that AVP, via activation of V1 receptors, is able to modulate positively contractile activity of longitudinal muscle of mouse distal colon, independently by enteric nerve activation and prostaglandin synthesis. Contractile response is achieved by increase in cytoplasmatic $\mathrm{Ca}^{2+}$ concentration via extracellular $\mathrm{Ca}^{2+}$ influx from L-type $\mathrm{Ca}^{2+}$ channels and via $\mathrm{Ca}^{2+}$ release from intracellular stores through phospholipase $\mathrm{C}$ pathway. No modulation has been observed on the contractility of the circular muscle.
\end{abstract}

() 2013 Elsevier B.V. All rights reserved.

\section{Introduction}

Arginine-vasopressin (AVP), also known as antidiuretic hormone, is a peptide hormone synthesized in the hypothalamus which plays a major role in maintaining cardiovascular and body fluid homeostasis. In addition, it exerts a variety of physiological effects on various tissues and cells, including promotion of blood coagulation, glycolysis and cell proliferation $[1,2]$.

The multiple actions of AVP are mediated by members of G-proteincoupled receptor family divided into three subtypes: V1 receptors (known as V1a), V2 receptors and V3 receptors (previously known as V1b) [2,3]. V1 receptors (known as V1a) are involved in the regulation of blood pressure [4] and are expressed in various tissues including vascular smooth muscle cells where their activation causes vasoconstriction [5]. V2 receptors are expressed in the kidney collecting

Abbreviations: AVP, arginine vasopressin; CCh, carbachol; CPA, cyclopiazonic acid; DDA, 2',3'-dideoxyadenosine; EGTA, ethylene glycol-bis( $\beta$-aminoethyl ether)-N,N, $\mathrm{N}^{\prime}, \mathrm{N}^{\prime}$-tetraacetic acid tetrasodium salt; GI, gastrointestinal; U-73122, \{1-[6((17 $\beta-3-$ methoxyestra-1,3,5(10)-trien-17-yl)amino)hexyl]-1H-pyrrole-2,5-dione\}; PLC, phospholipase C; TTX, tetrodotoxin; V-1880, [deamino-Pen1,O-Me-Tyr2,Arg8]-Vasopressin.

* Corresponding author at: Dipartimento di Scienze e Tecnologie Biologiche, Chimiche e Farmaceutiche (STEBICEF) Laboratorio di Fisiologia generale, Università di Palermo, Viale delle Scienze, 90128 Palermo, Italy. Tel.: + 3909123897509 ; fax: + 390916577501.

E-mail address: rosa.serio@unipa.it (R. Serio). duct and are responsible for the antidiuretic effects [4,5]. V3 receptors are involved in the regulation of the hypothalamic-pituitary-adrenal stress axis [6,7]. V1a and V1b receptors effectively couple to Gq and phospholipase C pathway, V2 receptors couple to Gs and adenylyl cyclase pathway [2]. Moreover, $\mathrm{V} 1$ receptors via phospholipase $\mathrm{A}_{2}$ /cyclooxygenase pathway may induce prostaglandin $E_{2}$ production in different organs and tissues [8,9].

Although it is well known that AVP is secreted into the circulation from the neurohypophysis in response to various factors, including increases in plasma osmolality, emotional stress, emesis, etc., different studies indicate the existence of peripheral site of production for this hormone as the gut [10-13]. Moreover, most of the factors triggering AVP release (plasma osmolality, stress, emesis etc.) have also an impact on gastrointestinal (GI) function. AVP has been reported to regulate electrolyte and water transport in the colon both in vivo and in vitro. In vivo, in the rat and human colon AVP inhibits $\mathrm{Na}^{+}$and $\mathrm{Cl}^{-}$absorption $[14,15]$. By the contrast, AVP, stimulates in vitro $\mathrm{NaCl}$ and water absorption, as well as inhibits $\mathrm{Cl}^{-}$secretion in mouse, rat and human colon [16-21]. Unclear and conflicting are the studies about a possible effect of AVP in the control of gastrointestinal motility. Voderholzer et al. [22] suggested that AVP at physiological level might not influence colonic motility in rats and humans. Ward et al. [23] reported that AVP at low concentration increased slow wave activity and phasic contraction in the muscle strips from dog colon, whilst at higher concentration 
it caused an inhibitory effect. Moreover, the presence of AVP receptor mRNA at various levels along the GI tract has been demonstrated in humans [6] and V1a receptors has been found on the neurons of myenteric plexus in rat stomach, where AVP has been suggested to act as neuromodulator of enteric cholinergic neurons inducing excitatory effects on the contractility [24]. Recently AVP was shown to inhibit the contractions through production of nitric oxide in strips of the circular muscle of rat colon [25]. All together these data would suggest that AVP may be one of the brain-gut peptides influencing gastrointestinal functions also acting at peripheral level.

Thus, taken into account that the role of AVP in the bowel motility is far from being clear, and that in mouse colon a recent study indicates that another hormone, i.e. angiotensin II, involved in water control balance [26] is able to modulate colonic contractility, the aim of this study was to analyze pharmacologically the effects of AVP on mouse distal colon motility, to characterize the subtype(s) of receptor(s) involved and to investigate the action mechanism.

\section{Materials and methods}

All animal procedures were in conformity with the Italian D.L. no. 116 of 27 January 1992 and associated guidelines in the European Communities Council Directive of 24 November 1986 (86/609/ECC). Adult male mice (C57BL/10SnJ; weighing $25.5 \pm 0.5 \mathrm{~g}$ ), obtained from Charles River Laboratories (Calco - Lecco, Italy), were housed in groups (five per cage), under controlled conditions (12/12 light/dark cycle; ambient temperature $22 \pm 1{ }^{\circ} \mathrm{C}$; humidity $55 \pm 5 \%$ ) and they had free access to tap water and standard pellet food. Experimental procedures were approved by Ministero della Sanità (Rome, Italy).

\subsection{Recording of mechanical activity}

The method has been described previously $[27,28]$ with some modification. Briefly, mice were euthanized using isoflurane anesthesia followed by cervical dislocation. The abdomen was immediately opened, and the colon was removed and placed in Krebs solution consisting of $(\mathrm{mM})$ : $\mathrm{NaCl}=119 ; \mathrm{KCl}=4.5 ; \mathrm{MgSO}_{4}=2.5 ; \mathrm{NaHCO}_{3}=25 ; \mathrm{KH}_{2} \mathrm{PO}_{4}=1.2 ;$ $\mathrm{CaCl}_{2}=2.5$; and glucose $=11.1$. Circular or longitudinal muscle strips (20 $\mathrm{mm}$ in length) of mouse distal colon (about $5 \mathrm{~mm}$ proximal to the anus) were suspended in a $10-\mathrm{mL}$ organ bath with oxygenated $\left(95 \% \mathrm{O}_{2}\right.$ and $5 \% \mathrm{CO}_{2}$ ) Krebs solution $\left(37^{\circ} \mathrm{C}\right)$. The distal end of each strip was tied to an organ holder and the proximal end was secured with a silk thread to an isometric force transducer (FORT 25, Ugo Basile, Biological Research Apparatus, Comerio, VA, Italy). Mechanical activity was digitized on an A/D converter, visualized, recorded and analyzed on a personal computer using the PowerLab/400 system (Ugo Basile, Italy). Preparations were subjected to an initial tension of $200 \mathrm{mg}$ and were allowed to equilibrate for at least $30 \mathrm{~min}$. Rhythmic spontaneous contractions of varying amplitude developed in all preparations.

\subsection{Experimental protocol}

After the equilibration time, preparations were challenged with $0.1 \mu \mathrm{M}$ isoproterenol or with $10 \mu \mathrm{M}$ carbachol (CCh) for $2 \mathrm{~min}$, until stable responses were obtained. The contractile response to $\mathrm{CCh}$ in circular and longitudinal muscle strips was $1.06 \pm 0.18 \mathrm{~g}$ and $1.32 \pm 0.19 \mathrm{~g}$ $(\mathrm{n}=48)$, respectively. The inhibitory response to isoproterenol in circular muscle strips was $0.20 \pm 0.02 \mathrm{~g}(\mathrm{n}=48)$, whilst in longitudinal strips was $0.23 \pm 0.07 \mathrm{~g}(\mathrm{n}=48)$. Concentration-dependent curves for vasopressin were constructed by non cumulative addition of the drug before and after the different drugs. Vasopressin was applied for approximately $3 \mathrm{~min}$ at $30 \mathrm{~min}$ intervals. Time control experiments showed that a second curve to the agonist was reproducible. Tetrodotoxin (TTX) or atropine was tested against a sub-maximal dose of AVP. To investigate the role of extracellular $\mathrm{Ca}^{2+}$ ions in the vasopressin contractions, nifedipine, L-type voltage-dependent calcium channel blocker, or a calcium free solution were used. Calcium free solution was made by omitting $\mathrm{CaCl}_{2}$ from the control Krebs solution with the addition of $100 \mu \mathrm{M}$ ethylene glycol-bis( $\beta$-aminoethyl ether)- $\mathrm{N}, \mathrm{N}, \mathrm{N}^{\prime}, \mathrm{N}^{\prime}-$ tetraacetic acid tetrasodium salt (EGTA). To deplete the intracellular calcium stores tissue was incubated in $\mathrm{Ca}^{2+}$-free solution and in the presence of cyclopiazonic acid (CPA, $10 \mu \mathrm{M})$ for $15 \mathrm{~min}$ and subsequent exposures to carbachol $(10 \mu \mathrm{M})$ were repeated until carbachol had no contractile effects [29]. Vasopressin was tested also in the presence of U-73122, a widely used specific inhibitor of phospholipase C, indomethacin, a cyclooxygenase inhibitor, and in the presence of DDA, an adenylyl cyclase inhibitor. Lastly, we tested the effects of $0.1 \mu \mathrm{M}$ oxytocin. All antagonists/inhibitors were left in contact to the tissue for at least 30 min adding AVP. Concentrations of the drugs used were determined from the literature.

\subsection{Solution and drugs}

The following drugs were used: carbachol (CCh), cyclopiazonic acid (CPA), 2',3'-dideoxyadenosine (DDA), ethylene glycol-bis( $\beta$-aminoethyl

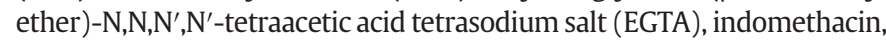
isoproterenol, nifedipine, tetrodotoxin (TTX), [deamino-Pen1, O-MeTyr2, Arg8]-vasopressin (V-1880) (all purchased from Sigma-Aldrich, Inc., St. Louis, USA); arginine vasopressin (AVP) and oxytocin (Tocris Bioscience, Bristol, UK); \{1-[6((17ß-3-methoxyestra-1,3,5(10)-trien-17yl)amino)hexyl]-1H-pyrrole-2,5-dione) (U-73122) (Calbiochem, Darmstadt, Germany). Indomethacin solution was prepared fresh on the day of experiment in $2 \%$ sodium carbonate solution and the $\mathrm{pH}$ was adjusted to 7.4. U-73122 and DDA were dissolved in dimethyl sulfoxide and nifedipine was dissolved in ethanol and further diluted in Krebs. All the other drugs were dissolved in distilled water. Control experiments using the different solvents alone showed that none had effects on the tissue responses that were studied. The working solutions were prepared fresh on the day of the experiment by diluting the stock solutions in Krebs.

\subsection{Statistical analysis}

All data are presented as means \pm SEM: ' $n$ ' indicates the number of animal preparations. Contractile responses induced by AVP were reported as a percentage of the effect induced by $10 \mu \mathrm{M}$ CCh. AVP responses were fitted to sigmoid curves (Prism 4.0, Graph-PAD, San Diego, CA, USA) and $\mathrm{EC}_{50}$ values with $95 \%$ confidence limits (CLs) were determined. Statistically significant differences were calculated by Student's $t$-test. $\mathrm{P}<0.05$ was considered statistically significant.

\section{Results}

Circular and longitudinal muscle strips of mouse distal colon displayed spontaneous activity consisting of phasic contractions with amplitude of $238.8 \pm 0.5 \mathrm{mg}$ and $244.2 \pm 0.8 \mathrm{mg}(\mathrm{n}=20)$, a frequency of $4.2 \pm 1.5$ c.p.m. and $5.2 \pm 1.5$ c.p.m $(\mathrm{n}=20)$, respectively. AVP $(0.001 \mathrm{nM}-100 \mathrm{nM})$ was without any effects on the circular muscle, whilst it caused concentration-dependent contractile effects on the longitudinal muscle $\left(\mathrm{EC}_{50}=0.05 \mathrm{nM} ; 95 \% \mathrm{CL} 0.03-\right.$ $0.1 \mathrm{nM}, \mathrm{n}=10$ ) (Figs. 1, 2). These effects lasted throughout the drug application time. The maximal response was observed at the dose of $100 \mathrm{nM}$ consisting in an absolute increase in muscular tone of $580 \pm 7.6 \mathrm{mg}(\mathrm{n}=10)$. We never observed an inhibitory effect in response to AVP, even at higher concentrations. The possible involvement of $\mathrm{V} 1$ receptor subtype in the response to AVP was tested using, a potent V1 receptor antagonist, V-1880. V-1880 (30 nM), which per se did not modify spontaneous activity (the amplitude and frequency of the spontaneous contraction was $249.1 \pm 0.9 \mathrm{mg}$ and $5.0 \pm 1.2$ c.p.m. in the presence of $\mathrm{V}-1880, \mathrm{n}=10$ ), shifted to the right the concentration-response curve to AVP $\left(\mathrm{EC}_{50}=0.9 \mathrm{nM}\right.$; 95\% CL 0.6-1 nM, $\mathrm{n}=10$ ) (Fig. 2). 
CIRCULAR MUSCLE

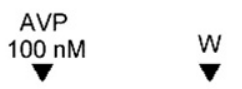

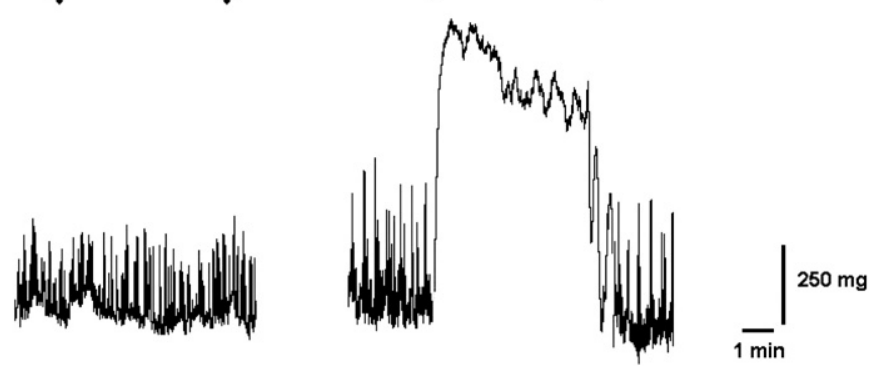

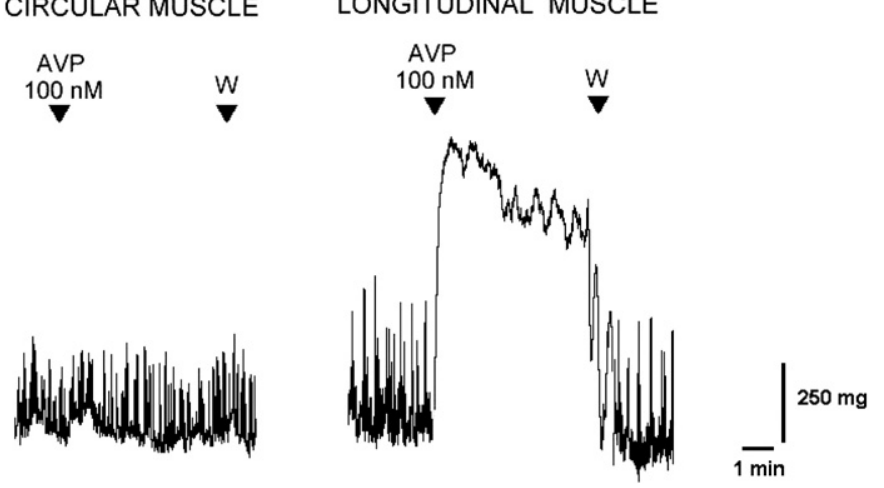

\section{AVP}

$\boldsymbol{\nabla}^{\mathrm{nM}}$

W

Fig. 1. AVP induced a contractile response only in the longitudinal muscle of mouse distal colon. Original recordings showing the effects evoked by AVP in circular and longitudinal of mouse distal colon.

AVP-induced effect was not modified in the presence of a $\mathrm{Na}^{+}$ voltage-gated neural channel blocker, TTX $(1 \mu \mathrm{M})$, or atropine $(1 \mu \mathrm{M})$, a muscarinic receptor blocker, or indomethacin $(10 \mu \mathrm{M})$, a cyclooxygenase inhibitor (Fig. 3). None of these agents had any effect on the spontaneous mechanical activity. The amplitude and frequency of the spontaneous contraction was: $209.1 \pm 1.2 \mathrm{mg}$ and $4.8 \pm 1.4$ c.p.m. in the presence of TTX $(\mathrm{n}=5) ; 191.3 \pm 2.2 \mathrm{mg}$ and $5.3 \pm 0.9$ c.p.m. in the presence of atropine $(\mathrm{n}=5)$; or $234.8 \pm 0.9 \mathrm{mg}$ and $5.2 \pm 1.3$ c.p.m. in the presence of indomethacin $(n=5)$.

In $\mathrm{Ca}^{2+}$-free solution or in the presence of a L-type calcium channel blocker, nifedipine (10 $\mathrm{nM}$ ), the contractile response to the submaximal dose of AVP (10 nM) was reduced to about $30 \%$ of the control (Fig. 4). The amplitude and frequency of the spontaneous contraction was $81.1 \pm 0.9 \mathrm{mg}$ and $1.2 \pm 0.6$ c.p.m. in $\mathrm{Ca}^{2+}$-free solution $(\mathrm{n}=5)$; $83.2 \pm 0.7 \mathrm{mg}$ and $1.6 \pm 0.7$ c.p.m. in the presence of nifedipine $(\mathrm{n}=5)$. Contractile response to AVP was, also, tested after depletion

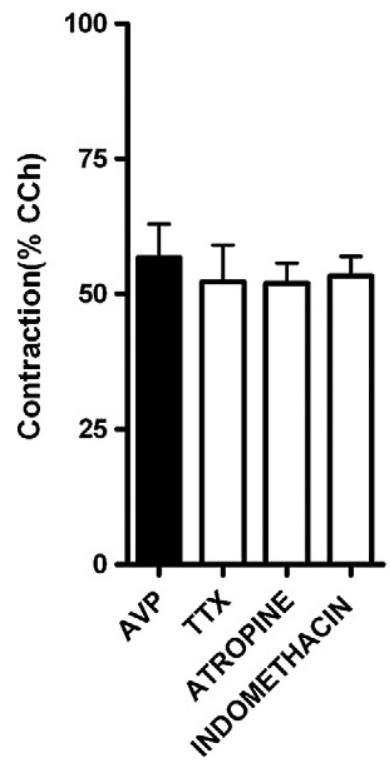

Fig. 3. AVP contractile responses are independent by enteric nerve activation and prostaglandin synthesis. Histogram showing the effects of AVP $(10 \mathrm{nM})$ in the absence or in the presence of TTX $(1 \mu \mathrm{M}), \mathrm{Na}^{+}$voltage-gated neural channel blocker, atropine $(1 \mu \mathrm{M})$, muscarinic receptor antagonist, or indomethacin $(10 \mu \mathrm{M})$, cyclooxygenase inhibitor, in the longitudinal muscle of mouse distal colon. Data are means \pm SEM $(n=5$ each) and are expressed as percentage of the maximal effect induced by $10 \mu \mathrm{M}$ CCh. The graphed value for the control bar is the mean of the control data obtained before each treatment.

of calcium intracellular stores. Depletion of calcium intracellular stores was induced by repetitive challenges with carbachol $(10 \mu \mathrm{M})$, cholinergic agonist, which mobilized calcium from intracellular stores, in calcium-free medium and in the presence of CPA $(10 \mu \mathrm{M})$, to block reuptake of $\mathrm{Ca}^{2+}$ by sarcoplasmic reticulum-specific $\mathrm{Ca}^{2+}$-ATPase. AVP was tested once CCh had no effect on the colonic muscle. In
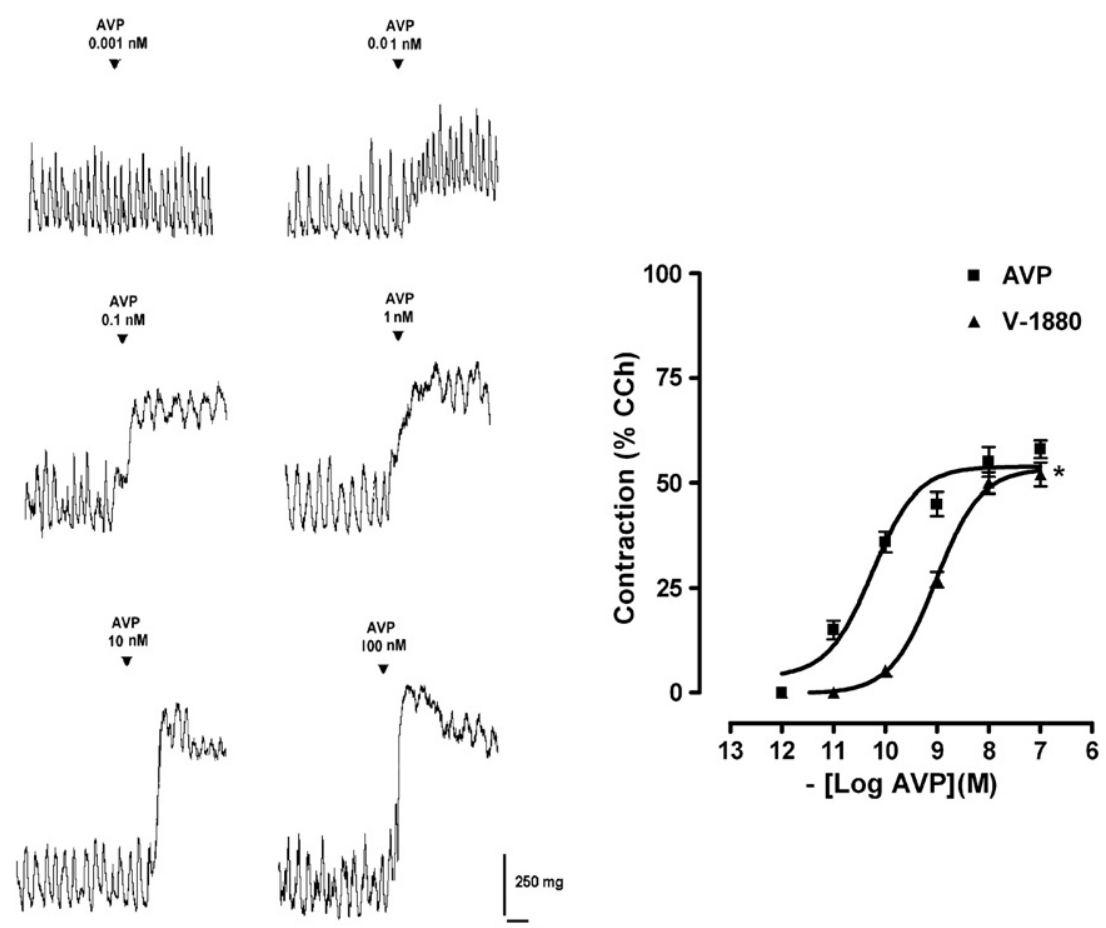

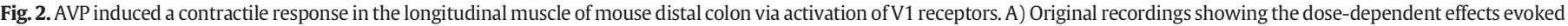

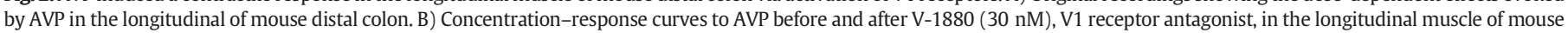
distal colon. Data are means \pm SEM $(n=10)$ and are expressed as percentage of the maximal effect induced by $10 \mu \mathrm{M} C C h$. *P $<0.05$ versus control. 


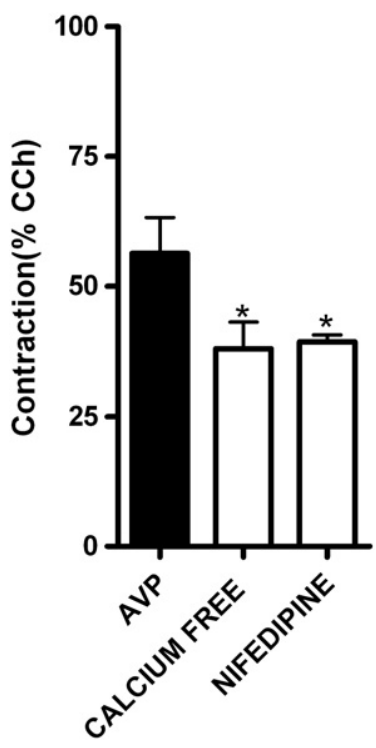

Fig. 4. AVP contractile responses require $\mathrm{Ca}^{2+}$ influx from L-type channel. Histogram showing the effects of AVP $(10 \mathrm{nM})$ in longitudinal muscle of mouse distal colon in control condition, in $\mathrm{Ca}^{2+}$-free solution or in the presence of nifedipine $(10 \mathrm{nM})$, L-type calcium channel blocker, in the longitudinal muscle of mouse distal colon. Data are means \pm SEM ( $n=5$ each) and are expressed as percentage of the maximal effect induced by $10 \mu \mathrm{M}$ CCh. The graphed value for the control bar is the mean of the control data obtained before each treatment. ${ }^{*} \mathrm{P}<0.05$ when compared to the respective own control condition.

this condition, the contractile response to AVP (10 nM) was abolished, indicating mobilization of calcium from intracellular stores after activation of V1 receptors (Fig. 5).

Since intracellular $\mathrm{Ca}^{2+}$ release from the sarcoplasmic reticulum is accomplished in the gastrointestinal muscle by activation of intracellular signaling transduction, the excitatory effect induced of submaximal dose of AVP was tested in the presence of U-73122, an inhibitor of the PLC, and in the presence of DDA, an adenylyl cyclase inhibitor. U-73122 $(50 \mu \mathrm{M})$ antagonized the response by $70 \%$, whilst, as expected, DDA (10 $\mu \mathrm{M})$ was without any effect (Fig. 6).

Lastly, we tested the effects of oxytocin, which differs from AVP by only two amino acids, since it is reported to modulate intestinal motility in rats [24]. In our preparation, oxytocin induced an excitatory effect in the longitudinal muscle of distal colon only at very high concentrations, from $0.1 \mu \mathrm{M}$. However, this effect was antagonized by V-1880 (30 nM), indicating an aspecific binding of oxytocin to V1 receptors (data not shown).

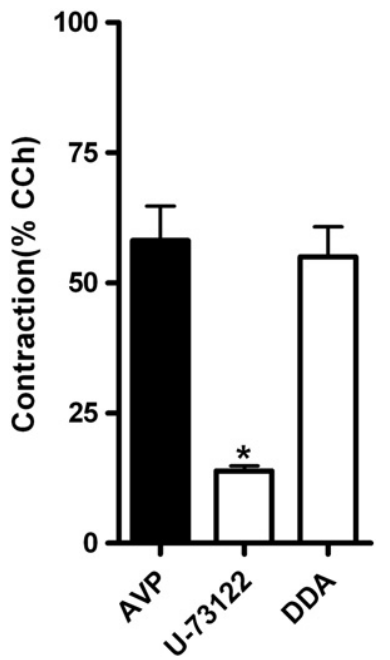

Fig. 6. Phospholipase $\mathrm{C}$ is activated by V1 receptors. Histogram showing the effects of AVP $(10 \mathrm{nM})$, in the absence or in the presence of U-73122 $(50 \mu \mathrm{M})$, an inhibitor of the phospholipase C, or DDA (10 $\mu \mathrm{M})$, an adenylyl cyclase inhibitor, in the longitudinal muscle of mouse distal colon. Data are means $\pm \operatorname{SEM}(n=5$ each) and are expressed as percentage of the maximal effect induced by $10 \mu \mathrm{M}$ CCh. The graphed value for the control bar is the mean of the control data obtained before each treatment. ${ }^{*} \mathrm{P}<0.05$ when compared to the respective own control condition.

\section{Discussion}

The results of this study show that AVP, via activation of V1 receptors, is able to modulate positively the contractile activity of longitudinal muscle of mouse distal colon, independently by enteric nerve activation and prostaglandin synthesis. Contractile response is achieved by increase in cytoplasmatic $\mathrm{Ca}^{2+}$ concentration via extracellular $\mathrm{Ca}^{2+}$ influx from L-type $\mathrm{Ca}^{2+}$ channels and via $\mathrm{Ca}^{2+}$ release from intracellular stores through PLC pathway. No modulation has been observed on the contractility of the circular muscle.

The role of AVP in the regulation of free water reabsorption, body fluid osmolality, blood volume, blood pressure, cell contraction, cell proliferation, and adrenocorticotropin secretion, is well known, but different experimental evidences suggest an involvement of this hormone also in the control of GI functions [30]. In humans, intravenous administration of AVP, used in the treatment of upper GI hemorrhages, causes abdominal cramps and a strong urge to defecate, likely by stimulating colonic motility [31]. Either central or peripheral site of action have been reported [32].

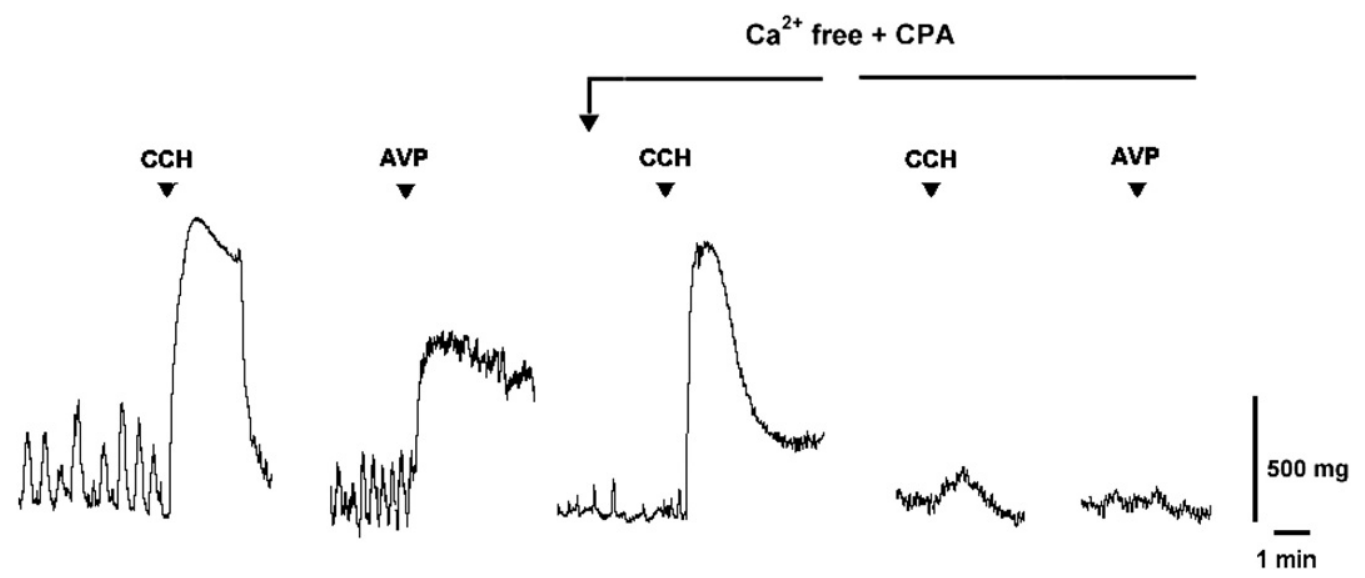

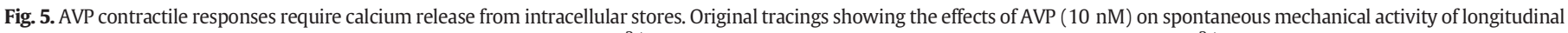

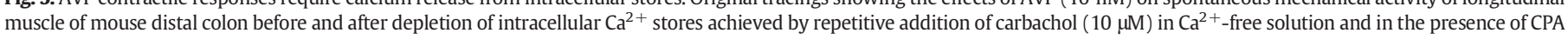
$(10 \mu \mathrm{M})$. Note that in this condition, the contractile response to AVP was abolished. 
Indeed AVP can be produced locally in cells of human and rat gastrointestinal system [33] and AVP receptors are reported to be expressed throughout gastrointestinal tract $[6,24]$. However, there are contradictory reports of the effects of vasopressin being different the responses in the various parts of the GI tract and among species. In our experiments, AVP induces a concentration-dependent contractile response on the longitudinal muscle of mouse distal colon by activation of specific V1 receptors, as shown by the sensitivity of the response to the selective V1 receptor antagonist V-1880. Actually, local V1 receptors mediating either AVP excitatory or inhibitory effects have been reported in other animal preparations [23-25].

In our preparations, we never observed inhibitory effects of AVP even at the higher concentrations, although tissues were able to relax in response of isoproterenol. Intriguingly, AVP responses can be selectively seen only in longitudinal muscle strips, being AVP ineffective, at our concentration range, on the circular muscle. It has been reported that in mouse gastrointestinal muscle there is a different sensitivity of the two muscular layers to pharmacological drugs, being the longitudinal muscle layer more responsive to excitatory agents than the circular muscle layer [34]. However, we cannot exclude that AVP may induce both inhibitory and excitatory effects on the circular muscle which will counterbalance each other. In any case, the excitatory effects induced on the longitudinal muscle may contribute to determine the overall muscular tone instead of propulsive motor activity. Tonic activity would allow homogenizing of the luminal contents and increasing both the pressure and the area of their contact with the mucosal surface, facilitating water and salt absorption.

Moreover, the contractile effects induced by AVP were insensitive to drugs blocking neural conduction and cholinergic neurotransmission, indicating a recruitment of post-junctional V1 receptors. This conclusion is in agreement to results obtained in dog proximal colon [23], but it is in contrast with other studies in monkey and rats [24,25,31], which suggest neural mechanisms underlying AVP effects, strengthened species differences in the response to AVP.

Further, our study demonstrated that contractile effects of AVP are dependent upon increase in intracellular $\mathrm{Ca}^{2+}$ concentration due to $\mathrm{Ca}^{2+}$ influx from extracellular space via L-type $\mathrm{Ca}^{2+}$ channels nifedipine-sensitive and $\mathrm{Ca}^{2+}$ release from internal stores. Moreover, we showed that contractile responses to AVP were reduced in the presence of the PLC inhibitor, U-73122, indicating that, also in our preparation, V1 receptors are coupled to the Gq protein/PLC $\beta$ pathway leading to the increase in intracellular calcium concentration by release from intracellular stores. In addition, AVP, via activation of $V 1$ receptors/phospholipase $A_{2}$ /cyclooxygenase, has been shown to stimulate prostaglandin $E_{2}$ production human fibroblasts [9]. However, in our preparation, prostaglandin synthesis seems not to be involved in the excitatory effects to AVP due to the insensitivity of the contractile response to indomethacin. As expected, AVP responses were resistant to adenylyl cyclase inhibitor and this observation may allow us also to exclude an involvement of V2 receptors, generally linked to adenylyl cyclase activation and increase of intracellular cAMP.

Physiological plasma levels of AVP in rat and in mouse were comparable to those in human, being in the order of $10^{-11} \mathrm{M}$ $[35,36]$. In our experiments, AVP at such concentrations marginally influences colonic motility, as reported in rat colon [37], contributing to the maintenance of muscular tone. This effect will be amplified when higher plasma concentrations of AVP will be reached, as after water deprivation [35] at the early stage of septic shock [38-40] in various chronic inflammatory states [41,42], and during the treatment of critical illness $[43,44]$.

In addition, expression of AVP-like immunoreactivity was found in the GI wall, increasing in oral to aboral direction [12,13,23,31,45], suggesting a possible local source of AVP that increasing AVP level over the circulating concentration may be one of the factors regulating colonic motility. Therefore, as suggested for angiotensin II [26], the modulation of the colonic contractility and the consequent impact on motility pattern can be one of the mechanisms by which AVP would control body fluid and electrolyte homeostasis.

Lastly, AVP differs from oxytocin by only two amino acids. Oxytocin has been reported to induce in rats excitatory effects on the gastric motility [24], but not on the colonic motility [46]. In our experiments, we could see an excitatory effect to oxytocin only at very high concentration (over $0.1 \mu \mathrm{M}$ ). This effect was antagonized in presence of the V1 receptors antagonist, V-1880, suggesting that, at such high concentrations, oxytocin interacts aspecifically with V1 receptors. Thus, similarly from what has been reported in rat colon [46], in mouse colon oxytocin seems not to play a role in the modulation of contractility.

In conclusion, in this study we reported that AVP can induce muscular contraction in longitudinal distal mouse by activation of V1 excitatory receptors located at the post-junctional level. V1 receptors determine increase in cytoplasmatic $\mathrm{Ca}^{2+}$ concentration via extracellular $\mathrm{Ca}^{2+}$ influx from L-type $\mathrm{Ca}^{2+}$ channels and via $\mathrm{Ca}^{2+}$ release from intracellular stores through PLC pathway. Overall our results underlie the possibility that AVP is able to modulate intestinal motility also acting at peripheral level, although its physiological significance remains to be elucidated.

\section{Acknowledgments}

This work was supported by a grant from Ministero dell'Università e della Ricerca Scientifica - Italy.

\section{References}

[1] Liu JP, Robinson PJ, Funder JW, Engler D. The biosynthesis and secretion of adrenocorticotropin by the ovine anterior pituitary is predominantly regulated by arginine vasopressin (AVP). Evidence that protein kinase C mediates the action of AVP. J Biol Chem 1992;265:14136-42.

[2] Koshimizu TA, Nakamura K, Egashira N, Hiroyama M, Nonoguchi H, Tanoue A. Vasopressin V1a and V1b receptors: from molecules to physiological systems. Physiol Rev 2012;92(4):1813-64.

[3] Birnbaumer M. Vasopressin receptors. Trends Endocrinol Metab 2000;11(10):406-10.

[4] Treschan TA, Peters J. The vasopressin system: physiology and clinical strategies. Anesthesiology 2006;105(3):599-612.

[5] Thibonnier M, Kilani A, Rahman M, DiBlasi TP, Warner K, Smith MC, Leenhardt AF, Brouard R. Effects of the nonpeptide V(1) vasopressin receptor antagonist SR49059 in hypertensive patients. Hypertension 1999;34(6):1293-300.

[6] Monstein HJ, Truedsson M, Ryberg A, Ohlsson B. Vasopressin receptor mRNA expression in the human gastrointestinal tract. Eur Surg Res 2008;40(1):34-40 [Epub].

[7] Ohlsson B, Björgell O, Ekberg O, Darwiche G. The oxytocin/vasopressin receptor antagonist atosiban delays the gastric emptying of a semisolid meal compared to saline in human. BMC Gastroenterol 2006;6:11.

[8] Fleisher-Berkovich S, Kagan E, Grossman N, Danon A. Multiple effects of arginine vasopressin on prostaglandin E2 synthesis in fibroblasts. Eur J Pharmacol 2004;485(1-3):53-9.

[9] Nakatani Y, Chin Y, Hara S, Kudo I. Immediate prostaglandin E2 synthesis in rat $3 Y 1$ fibroblasts following vasopressin V1a receptor stimulation. Biochem Biophys Res Commun 2007;354(3):676-80.

[10] Fuller PJ, Clements JA, Tregear GW, Nikolaidis I, Whitfeld PL, Funder JW. Vasopressinneurophysin II gene expression in the ovary: studies in Sprague-Dawley, Long-Evans and Brattleboro rats. J Endocrinol 1985;105(3):317-21.

[11] Lefebvre DL, Zingg HH. Novel vasopressin gene-related transcripts in rat testis. Mol Endocrinol 1991;5(5):645-52.

[12] Friedmann AS, Memoli VA, Cheng SW, Yu X, North WG. Vasopressin and vasopressin associated neurophysin are present in gastric and duodenal cells of Brattleboro and Long-Evans rats. Ann N Y Acad Sci 1993;689:522-5.

[13] Friedmann AS, Memoli VA, Yu XM, North WG. Biosynthesis of vasopressin by gastrointestinal cells of Brattleboro and Long-Evans rats. Peptides 1993;14:607-12.

[14] Dennhardt R, Lingelbach B, Haberich FJ. Intestinal absorption under the influence of vasopressin: studies in unanaesthetised rats. Gut 1979;20:107-13.

[15] Levitan R, Mauer I. Effect of intravenous antidiuretic hormone administration on salt and water absorption from the human colon. J Lab Clin Med 1968;72:739-46.

[16] Bridges RJ, Nell G, Rummel W. Influence of vasopressin and calcium on electrolyte transport across isolated colonic mucosa of the rat. J Physiol 1983;338:463-75.

[17] Bridges RJ, Rummel W, Wollenberg P. Effects of vasopressin on electrolyte transport across isolated colon from normal and dexamethasone-treated rats. J Physiol 1984;355:11-23.

[18] Knobloch SF, Diener M, Rummel W. Antisecretory effects of somatostatin and vasopressin in the rat colon descendens in vitro. Regul Pept 1989;25:75-85.

[19] Vincentini-Paulino MLM. In vitro action of vasopressin on water absorption by rat colon. Braz J Med Biol Res 1992;25:1041-3.

[20] Grady GF, Duhamel RC, Moore EW. Active transport of sodium by human colon in vitro. Gastroenterology 1970;59(4):583-8.

[21] Mobasheri A, Wray S, Marples D. Distribution of AQP2 and AQP3 water channels in human tissue microarrays. J Mol Histol 2005;36(1-2):1-14. 
[22] Voderholzer WA, Allescher HD, Muller-Lissner SA. The effect of hormones and peptides involved in water balance on rat colonic motility in vitro. Neurogastroenterol Motil 1995;7:15-21.

[23] Ward SM, Bayguinov OP, Lee HK, Sanders KM. Excitatory and inhibitory actions of vasopressin on colonic excitation-contraction coupling in dogs. Gastroenterology 1997; 113:1233-45.

[24] Junfang Qin, Liu Kejing, Wang Paulus S, Liu Chuanyong. V1 receptor in ENS mediates the excitatory effect of vasopressin on circular muscle strips of gastric body in vitro in rats. Regul Pept 2009;157(1-3):32-6.

[25] Jing H, Qin J, Feng M, Wang T, Zhu J, Wang C, Wang F, Liu K, Li J, Liu C. Nitric oxide in enteric nervous system mediated the inhibitory effect of vasopressin on the contraction of circular muscle strips from colon in male rats. Neurogastroenterol Motil 2011;23(3):125-35.

[26] Mastropaolo M, Zizzo MG, Mulé F, Serio R. Angiotensin II contractile effects in mouse colon: role for pre- and post-junctional AT1A receptors. Acta Physiol 2013;207:337-45.

[27] Zizzo M, Mastropaolo M, Lentini L, Mulè F, Serio R. Adenosine negatively regulates duodenal motility in mice: role of $\mathrm{A}(1)$ and $\mathrm{A}(2 \mathrm{~A})$ receptors. $\mathrm{Br} \mathrm{J}$ Pharmacol 2011;164:1580-9.

[28] Zizzo MG, Mastropaolo M, Grählert J, Mulè F, Serio R. Pharmacological characterization of uracil nucleotide-preferring P2Y receptors modulating intestinal motility: a study on mouse ileum. Purinergic Signal 2012;8:275-85.

[29] Zizzo MG, Mulè F, Serio R. Activation of P2Y receptors by ATP and by its analogue, ADPbetaS, triggers two calcium signal pathways in the longitudinal muscle of mouse distal colon. Eur J Pharmacol 2008;595:84-9.

[30] Schapiro H, Britt LG. The action of vasopressin on the gastrointestinal tract. A review of the literature. Am J Dig Dis 1972;17(7):649-67.

[31] Zhu YR, Cowles VE, Herranz ES, Schulte WJ, Condon RE. Arginine vasopressin inhibits phasic contractions and stimulates giant contractions in monkey colon. Gastroenterology 1992;102(3):868-74.

[32] Bueno L, Gue M, Delrio C. CNS vasopressin mediates emotional stress and CRHinduced colonic motor alterations in rats. Am J Physiol 1992;262:427-31.

[33] Friedmann AS, Memoli VA, North WG. Evidence for vasopressin production in the human gastrointestinal system. Peptides 1991;12(5):1051-6.

[34] Daniel EE, Boddy G, Bong A, Cho WJ. A new model of pacing in the mouse intestine. Am J Physiol Gastrointest Liver Physiol 2004;286:253-62.
[35] Oliverio MI, Delnomdedieu M, Best CF, Li P, Morris M, Callahan MF, Johnson GA, Smithies O, Coffman TM. Abnormal water metabolism in mice lacking the type $1 \mathrm{~A}$ receptor for ANG II. Am J Physiol Renal Physiol 2000;278:75-82.

[36] Yang Y, Huang W, Lu X. Early changes of endothelin, nitric oxide and argininevasopressin in patients with acute cerebral injury. Chin J Traumatol 2002;5:259-62.

[37] Voderholzer WA, Klauser AG, Muhldorfer BE, Fiedler F, Muller-Lissner SA. The influence of arginine-vasopressin on stool output and gastrointestinal transit time in healthy volunteers. Z Gastroenterol 1995;33:189-92.

[38] Wilson MF, Brackett DJ, Hinshaw LB, Tompkins P, Archer LT, Benjamin BA. Vasopressin release during sepsis and septic shock in baboons and dogs. Surg Gynecol Obstet 1981;153:869-72.

[39] Sharshar T, Blanchard A, Paillard M, Raphael JC, Gajdos P, Annane D. Circulating vasopressin levels in septic shock. Crit Care Med 2003;31:1752-8.

[40] Jochberger S, Luckner G, Mayr VD, Wenzel V, Morgenthaler NG, Friesenecker BE Hasibeder WR, Dünser MW. Course of vasopressin and copeptin plasma concentrations in a patient with severe septic shock. Anaesth Intensive Care 2006;34:498-500.

[41] Girón-González JA, Martínez-Sierra C, Rodriguez-Ramos C, Macías MA, Rendón P, Díaz F, Fernández-Gutiérrez C, Martín-Herrera L. Implication of inflammationrelated cytokines in the natural history of liver cirrhosis. Liver Int 2004;24:437-45.

[42] Han DM, Zhang YQ, Bai QX, Chen XQ. Assay of AVP, CRP, and LPS in leukemia. Int ] Lab Hematol 2007;29:185-9.

[43] Singer M. Arginine vasopressin vs. terlipressin in the treatment of shock states. Best Pract Res Clin Anaesthesiol 2008;22:359-68.

[44] Russell JA, Walley KR, Singer J, Gordon AC, Hébert PC, Cooper DJ, Holmes CL, Mehta S, Granton JT, Storms MM, Cook DJ, Presneill JJ, Ayers D, VASST Investigators. Vasopressin versus norepinephrine infusion in patients with septic shock. N Engl J Med 2008;358:877-87.

[45] Vasallo JL, Arreaza R, Muñoz-Barragán L. Immunocytochemical study of vasopressinlike immunoreactive material in the gastrointestinal tract of the hedgehog Erinaceus europaeus. Bol Asoc Med P R 1992;84:67-9.

[46] Ataka K, Nagaishi K, Asakawa A, Inui A, Fujimiya M. Alteration of antral and proximal colonic motility induced by chronic psychological stress involves central urocortin 3 and vasopressin in rats. Am J Physiol Gastrointest Liver Physiol 2012;303:519-28. 